\title{
Om højskole og kristendom
}

\author{
Af Harry Aronson
}

Knud Riis: Højskolens religion. Nornesalen og Kroghs Forlag A/S, Vejle 1998,359 s.

Genom stipendium från »Nornesalen. Forskningscenter for folkelig Livsoplysning « gavs möjligheten åt Knud Riis att genomföra ett studieprojekt som kom att omfatta såväl folkhögskolans i Danmarks samtidshistoria, med tonvikt på dess historiskt givna identitet, som olika Grundtvigtolkningar och Grundtvig själv.

Resultaten av dessa omfattande studier finns nu tillgängliga, dels som lån genom »Biblioteket for det folkelige Arbejde«, Ollerup, dels publicerade i bokform. Boken är dels självpresentationer av dette stort antal folkhögskolor i form av invigningstal 18921969, dels ett koncentrat av de mera omfattande otryckta analyserna av Grundtvig själv, Grundtvigtolkningar och senare trender i højskolens självförståelse. De opublicerade förstudierna innehåller folkningsteoretiska överväganden, men också mera ingående Grundtviganalyser och en värdering av Kaj Thanings Grundtvigtolkning. Det senare är viktigt med hänsyn till den betydelse Thanings tolkning haf inom Grundtvigforskningen och i højskolens självförståelse under senare årtionden. Ur Grundtvigstudiets synpunkt är därför också detta bakgrundsmaterial med dess omfattande referenser och djupanalyser av stort intresse.

Riis har med sina omfattande analyser på ett engagerat och polemiskt sätt fortsatt Grundtvigdebatten och än en gång satt højskolen under debatt. Därmed får vi åter höra den speciella tonart i dansk livsåskådningsdebatt som bl.a. Thaning och K.E. Løgstrup på sin tid slog an med ordet »opgør«. Riis' analyser är skarpa, modiga, ibland skoningslösa, men ockå med självironi och gott humör. En lång rad framträdande personer på scenen för den grundtvigska själsförståelsen passerar revy. En rad orter med efterhand legendarisk betydelse manas fram - Asperup, Krogerup, Skødstrup ... Här skapas efter andra världskriget och framöver de teologiska och filosofiska förutsättningarna för højskolens »religion «.

Författarens problemupplevelse är präglad av synen när ungdomarna tågar in i højskolen och frågan: »Vad har de i bagaget?« - Är de hel-skulariserade eller är deras mentala bagage fyllt av ungdomskultur, kanske religiös? Vad finns inne i skolhuset? I sina studier har Riis analyserat den amerikanska litteraturteoretikern Fish som lanserat tesen att texten inte betyder någonting. Han låter en student säga: »Är det bara vi - eller finns det en text i klassen? « Följfrågan uppstår: Är texten, om den föreligger, kanske tyst och tom? Blir all tolkning då beroende av »fortolkningsfællesskabet«?

Detta är utan tvekan en fruktbar problemupplevelse. Nutid och tradition ställs upp emot varandra som en utmaning och uppgift att ta sig an. Den traditionsmättade grundtvigska miljön ställer den i varje fall. På ett för boken typiskt okonventionellt sätt illustreras det på första sidan. Där ser vi att Grundtvig svävar över Ry Højskole: porträttet från 1872, med riddarkorset, är inkopierat $\mathrm{i}$ bilden av skolbyggnaden. Dannebrogen är hissad.

Men är han mer än en symbol? Finns han i klassen? Bidrar han till skolans identitet? Till dess metafysik, till dess »religion «? Och vad slags religion och livsförståelse står 
egentligen Grundtvig för? Hur har traditionen förvaltats, förvandlats eller rentav förvanskats?

För att få relief åt frågan om Grundtvigs teologiska typ går Riis till en bestämd Grundtvigtext: »Moses og Jesus «i Dansk Kirketidende 1852:44. Här framträder Grundtvigs position i förhållande till grundläggande lutherska tankestrukturer. Texten har ofta uppmärksammats. Henrik Scharling använde den 1891 i boken »Grundtvig eller Luther?« för att visa att Grundtvig fundamentalt avvek från Luther däri, att Grundtvig inte kände lagen. Därför kunde inte Grundtvig kallas profet, enligt Scharling, utan förblev diktare. Jag själv analyserade texten 1960, Thaning 1963.

För Riis blir den koncentrerade texten ett huvudstycke för att, i Scharlings anda, visa att Grundtvig sätter Luthers lag-evangeliumteologi ur spel. Grundtvig brukade inte lagens bruk. Han utesluter jo $\mathrm{t} \mathrm{o} \mathrm{m}$, som bekandt, de tio burdorden från den specifikt kristna barnaläran. För Riis blir den lutherska systematiken $\mathrm{i}$ form av lag-evangelium fundamental för att typbestämma Grundtvig. Författaren återkommer till temat i en kritisk analys av »århundredets foredrag «, hållet av Løgstrup på Krogerup Højskole 1950 och tryckt $\mathrm{i}$ »Heretica « samma år med titeln »Humanisme og kristendom«. Riis ser denna artikel som en vidareföring av problematiken i »Moses og Jesus«.

Med Luther som fundament levererar Riis här och annorstädes en skarp kritik av Løgstrups ideologikritiska sekulariseringsteologi, som var inspirerad av Friederich Gogarten och uppmuntrad på hemmaplan av Kaj Thaning. Kritikens utgångspunkt är därvidlag att Løgstrup med en viss självklarhet menar sig vidareföra Luther och Grundtvig. Antagandet att sekulariseringen fortlöper ubehindrat är för Riis inte självklar. Senare religioniseringstendenser bekräfter inte det antagandet, tycks han mena. Därför skulle inte heller denna teologi och ideologikritik ha praktisk relevans. Den ideologifria och religionsfria och naket naturliga människan finns kanske inte!

Riis har genom att konfrontera såväl Grundtvigs tänkanda som senare, tongivande tänkare i den eftergrundtviska miljön med den klassiska lutherska teologin gett relief åt debatten.

Av särskilt intresse för Grundvigforskningen är Riis' sakliga men kritiska uppgörelse med Kaj Thanings huvudtes i disputatsen »Menneske først«, 1963. Han kan omtala tesen att Grundtvigs huvudintresse efter 1832 var att skilja mänskligt och kristet åt som »Thanings monomane fastholdelse ved sin tese om adskillelsen af det menneskelige og det kristelige«. Riis tilltalas i viss mån av Thanings tes, men anmärker, att »hos Grundtvig er adskillelsen ikke nær så klar, som Thaning gør den til« (s 126 f). Grundtvig var, säger Riis, genomsyrad av kristendom, och ett kristligt förtecken kan spåras också där han själv menar sig tala »naturligt « om människan. Riis är överhuvudtaget kritisk till föreställningen att det går att finna människan i rent naturtillstånd, en föreställning han tycker sig ana $\mathrm{i}$ »människa-först «-tänkande, som kan utvecklas till »människa-först-ochsist«-tänkande.

Det är förtjänstfullt att Riis tagit på sig det tunga arbetet att, åtminstone delvis, följa Thaning i spåren (enbart hans disputats omfattar 800 sidor!). Grundtvigforskningen har efterhand blivit så omfattande att det är en krävande uppgift att överblicka enbart det som gjorts under Grundtvig-Selskabets 50-åriga historia.

Lag-evangelium hör till det klassiska protestantiska språkbruket och är en bärande del i Riis' argumentation. Men författaren är upptagen inte bara av teologi utan teologi som kulturfenomen. Han behöver en term för att karakterisera ett kulturinnehåll som är av betydelse för hans analyser och ställningstaganden. Han uppfinner för detta ändamål ordet »jesendom«. Det betecknar en kultur som påverkats av den kristna tron och trosinnehållet, men där samtidigt väsentliga element $\mathrm{i}$ det kristna trosinnehållet 
försvunnit under lagrindsprocessen. Det är alltså ur viss aspekt fråga om en förlustprocess och det är framförallt detta som Riis tar fasta på. Synd t ex uppfattas som öde, domsföreställningar försvinner, att människan behöver frälsning osv. Dogmatiken lakas ur. Etiken självständiggörs från religionen. Kvar inne i kulturen blir ett kristetkulturellt minimum, en gemensam egendom, nerärvd genom den historiska processen, men utan frälsande kraft. Jesus finns i historien och det är svårt att gå förbi honom. Men det hade varit lättare om man kunnat tala bara om och med Sokrates, tycks Hal Koch mena, när han står inför uppgiften att föra den medmänsklig dialog. Men det blir Jesus som idealfigur då, inte som frälsare eller försonare.

Begreppet jesendom blir för Riis ett instrument att kritiskt analysera tankesystem i närheten av højskolen. Løgstrup och hans koncept »den etiske fordring«, en etik utan kristen tro, drabbas. Vilhelm Grønbechs livsfilosofi ses som prototypen för jesendomen (s 179, 187). Med dessa namn är vi inne i den krets av højskolefolk som träffades $i$ Asperup prästgård från 1947 och ett flertal år framåt. Värd där var Kaj Thaning. Grønbech spelade stor roll för honom litterärt, genom kritiken av pilgrimskristendomen. Där kom också Ole Wivel 1950 - som sedan skulle återkomma med en sång till öppnandet av Båring højskole 1959, alldeles i närheten. Thaning personligen och miljön blev, säger Riis, ett samlingsmärke för den syn på højskolen som blev dominerande på 1950-talet och framöver. När jag själv som Grundtvigforskande gäst i Asperup på 1950talet umgicks med Kaj Thaning kunde jag höra ekon av den imponerande intellektuella verksamheten där.

En kraftfull gestalt bland højskoletänkarne, i samhället och i tiden kring andra världskriget och uppstädningen därefter, var Hal Koch. Koch spelade, som alla vet, en central roll som opinionsledare och samlande personlighet. Som föreläsare över Grundtvig väckte han på nytt intresset för Grundtvig under de kritiska åren. Dessa engagemang och strävanden ledde fram till skapandet av Krogerup Højskole - en skola för demokrati och humanitet. Koch var teolog och professor i kyrkohistoria.

Som tillika föreståndare för Krogerup blir han denna skolas talesman. Som sådan kommer han också att formulera en livssyn och diskutera policyn för skolan. Demokrati blir nu ett heligt ord, konstaterar Riis. Dialogen blir den fundamentala uppgiften. I analogi härmed tolkar han också det kristna evaneliets mening så: »Livets Indhold er Mødet med Medmennesket«. För Riis blir detta ett annat exempel på jesendom, en reduktion av det större kristna meningssammanhanget. Och ett belägg för »Kochs ånd, hans åndelige usikkerhed samt hans instituering af en ny, human etik« (s 190).

De personkritiska orden kommer utav författarens bekymmer för att de ledande opinionsbildarna i højskolemiljö omdefinierat kristendomen genom att sekularisera den (»Wivel, Løgstrup, Koch, Thaning $\mathrm{m}$ fl ...«). Man har, enligt Riis, utvecklat en livsförståelse som innebär övergång från kristendom till jesendom. Det är en livsförståelse som blir till praxis från 1950-talet och framåt och därför ett viktigt fenomen i sökandet efter højskolens »religion«, metafysik eller ideologi.

Intressant är Riis' noteringar att det också hos Grundtvig finns kristendom och jesendom blandat om vartannat, i hans verksamhet och i hans skriftliga kvarlåtenskap. De här nämnda, framstående højskoletänkarnas livstolkningar kan han därför rentav se som »en slags videreførelse af Grundtvigs projekt « (s 244). Står vi nu återigen inför dubbelheten genuin kristendom (»full gospel«) och kristna kulturavlagringar, alias jesendom, men denna gång hos Grundtvig själv? Det är frågan vart denna kulturiseing slutligen kan leda som är författarens huvudfråga.

Den bok Riis och Nornesalen har gett ut är ytterst inciterande och skärpt $\mathrm{i}$ de enskilda analyserna. Med stor uthållighet och kraft genomarbetar författaren också de 
svåraste och snårigaste sammanhang, ibland tvekande om han förstått det hela eller om vissa textsammanhang överhuvudtaget är begripliga. Problemmängden är nästan oöverskådlig och stoffmängden är nästan uöverkomlig. Det är också i de enskilda analyserna författaren har sin styrka. Här har jag mest uppehållit mig vid de principiella analyserna. Boken innehåller också 110 sidor i form av referat av højskoleinvigningar för att dokumentera utvecklingen av højskolens identitet. Dessa invigningstexter har naturligt nog skiftande kvalitet och är präglade av att vara högtidstal. En del ger rätt lite av innehåll för författarens syfte. Men de ger en samlad bild av 100 års skolbyggande och är som sådana fascinerande. Den s k Tvindsagen, den resande folkhögskolans affärer, får 44 sidor. Denna affär är väl mest av kulturpolitiskt intresse, men aktualiserar den danska folkhögskolans politiska ställning och status i samhället.

Författaren säger på ett ställe »vi i Ry« och presenterar sig därmed som praktiserande højskolemand, betraktande ungdomarna som marscherar in. - Vad har de i bagaget? Vad har Ry Højskole, med Grundtvig svävande över taken, i beredskap åt dem? Vad kan och vill de ta emot? Det är et pedagogiskt problem av rang - och även religionspedagogiskt, i den mån som religion i strikt mening är involverad.

Vill man »teologisera« inför denna uppgift, vilket författaren gör, är det bra att ha ett teologiskt koncept som är rymligt nog att inkludera natur och kultur. Lutherdomen, som ofta är författarens referens, hade denna förmåga att genom tankestrukturerna lag och evangelium andligt och världsligt regemente, skapa en allomfattande samhällssyntes. Detta ligger nu flera århundraden tillbaka. Men på grundval av en sådan teologi kunde en positiv förståelse av kulturen uppnås, liksom det gick att tala meningsfullt om skapelsen.

Det förefaller som om författaren hade intentioner i denna riktning, framförallt som en fortsatt reflexion över vad det lutherska lagbegreppet kan betyda i dag - den punkt där Grundtvig är svag eller talar i andra kategorier. Det är en intressant tankeram som, mera udgörd, kanske skulle minska det inslag av misstanke mot kulturutvecklingen (»jesendom«!) som författaren gång efter annan visar upp.

Ett genomtänkande av lag och skapelse, ett manifesterande av en skapelseteologi i »rätt « ordning - »lag och evangelium« gentemot den barthianska ordningsföljden »evangelium och lag« - skulle också minska tendensen till kristianisering, eller rentav »kristen först «, som författaren säger sig ha prövat, men övergivit.

Men varför gå till Tyskland när vi har ett fruktbart teolgiskt material på hemmaplan! Hos Grundtvig har vi ju upplägget till att särskilja vad som är allmänmänskligt och vad som är specifikt kristet. Att särskilja i praktiken är emellertid inte detsamma som att skilja åt i tankesammanhanget, trossammanhanget eller visionen. Mänskligt och kristet kan där vara en syntes, men av eskatologisk art.

För oss, som kanske står i skolan, gäller naturligtvis att beskriva kristendomen på ett icke-reduktionistiskt sätt, vilket Riis också starkt värnar om. Grundtvigs teologiska »barnalära « med grundstrukturen skapelse-grundskada-återställelse ger också möjlighet att översätta en bibliskt-kristen grundstruktur till en livssyn där skapelse-skada kan upplevas som giltig av flertalet människor, men där återställelsen kan ses som kristen eller något annat visionärt eller utopiskt. På denna grundval kan man ha en partiell samverkan mellan kristna och naturalister/rationalister, för attän en gång alludera på Grundtvig i inledningen till Nordens Mythologi - utan att någons egenart blir förtryckt.

Att reflektera över teologi och livstolkning har sina risker, det ser vi av Riis' bok, där åtskilliga tidigare bidragsgivare råkar ut för kritik. Riis själv kommer väl inte helt undan granskning, liksom mina kommentarer i denna anmälan. Men det är väl tros- och livsåskådningens villkor och det som ger den dess dynamik och impulser till fortsatt 
reflexion och konfrontation. Att denna reflexion är speciellt livlig i Danmark noterar gärna en svensk och förstår att det framförallt är giganterna Grundtvig och Kierkegaard som ger stoff til ständigt nya analyser och »opgør«.

Vad Grundtvig gett oss som ofrånkomligt arv att reflektera över, och praktisera, om vi så vill, är hur människans villkor ska kunna gestaltas som en verksamhet »for Mennesket) i Guds Billede« - som är en av Grundtvigs skoldefinitioner. Eller, lite annorlunda uttryckt: att verka för ett »Gudsbelätet värdigt människoliv«, som det hette i den lingske gymnastikrörelsen, ett av de få sammanhang där Grundtvig gjort sig gällande i Sverige. Och där dessutom en återexport till Danmark skedde!

Kanske är det då också så att vi oavlåtligen måste uppfinna »Gudbilledligheden « för varje särskild tid! Med allt risktagande det kan föra med sig, behöver det inte bli en förvanskning, utan snarare en inskrivning i livsförståelsen både av allmänmänsklig, existentiell erfarenhet och en möjlig erfarenhet av det specifika och exklusiva kristenlivet.

Luther eller Grundtvig - vi får tacka dem båda för att de har satt igång oss att bli trostänkare på ett sådant sätt, att det berör oss, så att vi aldrig kan sluta. Det tacket gäller också alla som visar sig i boken, så ock författaren!

\title{
Grundtvigs historiefilosofi til kritisk vurdering
}

\author{
Af Sigurd Aa. Arnes
}

Ole Vind: Grundtvigs historiefilosofi, Gyldendal, Kфbenhavn 1999, 645 s.

Innenfor Grundtvig-forskningen har det i de senere år vært en tydelig tendens til å stille det modne forfatterskapet $\mathrm{i}$ sentrum - $\mathrm{i}$ motsetning til den tidligere forsknings konsentrasjon om ungdomsverkene. Ole Vinds ferske doktoravhandling, Grundtvigs historiefilosofi, er i så måte tidstypisk. Til overmål handler den også om to av det senere forfatterskaps hovedverker Haandbog $i$ Verdens-Historien (1833 - 56) og Nordens Mythologi (1832) - med sideblikk til Christenhedens Syvstjerne (1860) og Kirke-Speil (1871). Mer og mer fremtrer 1830-årene for oss i dag som »høydedraget« i Grundtvigs forfatterskap. Det var jo også $d a$ hans salmediktning brøt frem med uhørt kraft.

Den ambisiøse tittelen på Vinds avhandling er altså Grundtvigs historiefilosofi, men den handler ikke bare om verker som vi i dag ville oppfatte som historieskrivning. Forfatteren beskjeftiger seg også med en håndbok $\mathrm{i}$ nordisk mytologi (Nordens Mythologi), et »kirkeligt Sagakvad« (Christenhedens Syvstjerne) og en kirkehistorie (Kirke-Speil) - tekster som vi jo ikke umiddelbart forbinder med en historiefilosofi.

Vind taler da også flere steder i sin avhandling om Grundtvigs »dobbelte bogholderi« av verdenshistorie og kirkehistorie, men egentlig har vi vel å gjøre med en slags tredelt »bogholderi« i og med at den førkristne nordiske myteverden også trekkes inn i fremstillingen. Først og fremst forteller dette sitt om hvor forskjellig Grundtvigs historiebegrep er fra vårt. 